\title{
Synergistic Efficacy of Phytochemical, Antioxidant and Bactericidal Properties of the Aerial Essential Oil of Laggera crispata
}

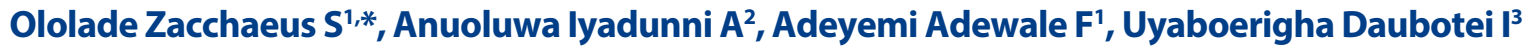

Ololade Zacchaeus $\mathbf{S}^{1, *}$,

Anuoluwa lyadunni $A^{2}$, Adeyemi

Adewale $\mathrm{F}^{1}$, Uyaboerigha

Daubotei $l^{3}$

'Department of Chemistry, University of Medical Sciences, Ondo, NIGERIA.

${ }^{2}$ Department of Biological Sciences, University of Medical Sciences, Ondo, NIGERIA.

${ }^{3}$ Department of Plant Biology and Biotechnology, University of Benin, NIGERIA.

\section{Correspondence}

Ololade Zacchaeus S

Department of Chemistry, University of

Medical Sciences, Ondo, NIGERIA

Phone no: +2348034836546

E-mail: sololade@unimed.edu.ng

zacchsnatpdt@gmail.com

History

- Submission Date: 11-05-2021

- Review completed: 13-06-2021;

- Accepted Date: 30-07-2021

DOI : 10.5530/pj.2021.13.165

Article Available online

http://www.phcogj.com/v13/i5

Copyright

(C) 2021 Phcogi.Com. This is an open access article distributed under the terms of the Creative Commons Attribution 4.0 International license.

\begin{abstract}
This study was undertaken to provide more scientific information about the phytochemical composition of Laggera crispata known for its medicinal uses. Essential oil was isolated by hydro-distillation, analysed using GC-MS, UV-Visible Spectrophotometer and other established biochemical assays were used for the study. The GC-MS analysis of the aerial essential oil of L. crispata showed the presence of 35 medicinal organic compounds making up $84.4 \%$ of the oil. The most abundant component was a phenolic compound called 2-tert-Butyl-1,4-dimethoxybenzene (54.5\%). The other major terpenoids present in the oil were $\alpha$-humulene $(6.9 \%)$ and (+)-sabinene $(5.9 \%)$. The TPC, TFC, TAA and TAC values of the aerial essential oil of $L$. crispata were $172.75 \pm 0.00 \mu \mathrm{gmg}^{-1} \mathrm{GAE}, 48.69 \pm 0.00 \mathrm{ggmg}^{-1} \mathrm{QE}, 61.85 \pm 0.00 \mathrm{\mu gmg}^{-1} \mathrm{AAE}$ and $726.92 \pm 0.00 \mathrm{mgmg}^{-1} \mathrm{AAE}$ respectively. DPPH IC ${ }_{50}$ and AAI values of the essential oil were $1.5 \mathrm{mgml}^{-1}$ and 26.7. The essential oil displayed varying inhibitory activities against Gram-positive and Gram-negative bacteria with zones of inhibition ranging from $08-30 \mathrm{~mm}$. The in vitro pharmacological activities added scientific support to the use of $L$. crispata in alternative and complementary medicine. The essential oil of L. crispata grown in Nigeria will play beneficial roles in human and animal health and therefore a research on this plant might be of great value in drug industries.

Key words: Laggera crispata, Asteraceae, Aerial essential oil, Secondary metabolites, Antioxidant, Antibacterial.
\end{abstract}

\section{INTRODUCTION}

Medicinal plants have been used in one form or another under indigenous systems of medicine. The secondary metabolites from plants are responsible for the medicinal activities of plants ${ }^{1-3}$. Medicinal plants appear to be rich in secondary metabolites, widely used in traditional medicine to combat and cure various ailments ${ }^{4,5}$. Medicinal plants are potent sources of compounds that can be used in the treatment of various human health challenges due to the active compounds that are responsible for their various pharmacological activities ${ }^{6-8}$. Natural products obtained from different plant sources are of remarkable medicinal value and are used to cure various diseases. The mitigative potential of natural products is used as a means of detoxification of poisonous agents in human and animals ${ }^{9-11}$. Researchers have isolated many medicinally active secondary metabolites from different medicinal plants $^{3,8,12}$. Among the various medicinal plants, odoriferous plants occupies an important place due to their aroma which is associated with the presence of essential oils, complex mixtures of volatile compounds, dominated by mono- and sesquiterpenes. In addition to essential oils, odoriferous plants are characterized by the presence of plant phenolic compounds, primarily coumarins and phenylpropanoids that have been shown to possess multiple pharmacological activities $^{13,14}$. Intensity in investigations of these secondary metabolites occurred as a result of side effects including toxicity, mutagenicity and carcinogenicity observed in some commercial synthetic antioxidants ${ }^{15,16}$

Essential oils are concentrated volatile aromatic compounds produced by plants; they are the essences which evaporate easily and give plants their wonderful scents. Each of these complex precious liquids is extracted from specific species of plant life ${ }^{17,18}$. Essential oils are natural products which can be extracted in a number of ways from plants; however, they are not formed/found in all plants. Essential oils extracted from plants contain aromatic properties used as remedies for a number of problems. Essential oils are used in aromatherapy practice to help ease muscle pain, emotional problems, menstrual issues, skin problems, arthritis and more ${ }^{19,20}$. Plant essential oils have been used for many thousands of years in food preservation, pharmaceuticals, alternative medicine and natural therapies, perfumes, aromatherapy, phototherapy, spices and nutrition ${ }^{14,21,22}$.

Essential oils from odoriferous medicinal plants exhibit high anti-viral potential against several types of many health damaging viruses (Herpes virus-1, Herpes virus-2, HIV, Adeno virus, Hepatitis B Virus, Enterovirus 71, JUNV, etc.) and even against SARSCoV- 1 which has $96 \%$ of the same genetic background with SARS-CoV-2 ${ }^{23-26}$. This evidence stemming from several experimental studies means that some compounds derived from essential oils could act as inhibitors of COVID-19. Essential oil molecules have ability to interact with the viral life cycle, such as the viral entry, replication, assembly, and release, as well as targeting virus-host through specific or non-covalent interactions such as hydrogen bonds, $\pi / \pi$ and van der Waals interactions ${ }^{27,28}$. Since the most important cause of COVID-19 related deaths is respiratory failure which is due to pneumonia and the overproduction of proinflammatory cytokines, molecules that act via anti-inflammatory mechanism of action are potential therapeutic agents since they 
can inhibit several proinflammatory cytokines ${ }^{26,29}$. Most essential oils exhibit antibacterial, antifungal, antiviral, insecticidal and antioxidant properties $^{30}$. Essential oils are believed to act as allelopathic agents or as irritants that protect plants from predation by insect and infestation by parasites. Essential oils and their constituents have also been shown to be a potent source of botanical pesticides ${ }^{14,20}$.

Laggera crispata (DC) Sch. Bip. is an annual shrub found growing as common weed in Nigeria. It belongs to the family Asteraceae and the genus consists of about 20 species. L. crispata is a widely distributed tropical medicinal plant with several therapeutic properties. The plant is spread throughout the sub-Saharan Africa and the tropical countries of Asia ${ }^{31}$. The medicinal plant is a robust herb that can grow up to 1.7 $\mathrm{m}$ in height. It is viscid and strongly aromatic. It has white flowers, and its basal leaves are bigger than the upper ones. In Nigeria, it is used traditionally for the treatment of athletes-foot, skin infections, pediatric malaria and wounds. It has also been reported for ethnomedicinal use as anti-inflammatory agent for treatment of hepatitis, arthritis, bronchitis and nephritis ${ }^{32,33}$.

\section{MATERIALS AND METHOD}

\section{Identification and Collection of Plant Material}

The plant was selected on the basis of intensive review and ethnopharmacological information. The fresh aerial of L. crispata was collected at different places in Ota, Nigeria and was identified as Laggera crispata.

\section{Extraction of the Essential Oil}

The air-dried aerial part of L. crispata was subjected to hydro-distillation for 3 hours using a Clevenger-type apparatus in accordance to British Pharmacopoeia methods. Distillate of the essential oil was dried over anhydrous sodium sulphate, after filtration, the essential oil was stored at $4^{\circ} \mathrm{C}$ until analyzed and used for various pharmacological tests ${ }^{34}$.

\section{Gas Chromatography-Mass Spectrometry (GC-MS) analysis and Compounds Identification}

The essential oil of L. crispata was analyzed by gas chromatographymass spectrometry (Shimadzu GC-MS-QP2010) instrument using a DBI column $(30 \mathrm{~mm} \times 0.25 \mathrm{~mm}$ ID $\times 0.25 \mu \mathrm{m}$, film thickness $)$. Constant flow at $1 \mathrm{ml} / \mathrm{min}$ of carrier gas (Helium) was used for sample analysis. The injector temperature of the instrument was programmed at $280^{\circ} \mathrm{C}$. Oven temperature was started from $40^{\circ} \mathrm{C}$ to $280^{\circ} \mathrm{C}$ with a ramp of $2^{\circ} \mathrm{C} /$ $\mathrm{min}$ and withholding time of $7.5 \mathrm{~min}$. The injection volumes were $1 \mu \mathrm{l}$. The temperature of the ion source was set at $280^{\circ} \mathrm{C}$. Ionization of the sample was performed in electron impact mode at an ionization voltage of $70 \mathrm{eV}$ with mass range used from $\mathrm{m} / \mathrm{z}$ 50-650. Interpretation of GC-MS data was performed using the database of Wiley and NIST libraries.

\section{Determination of Total Polyphenol Content (TPC)}

The TPC in the essential oil of L. crispata was determined using Folin-Ciocalteu method. Gallic acid was used as a standard phenolic compound. The solution contained $1 \mathrm{ml}$ of the essential oil solution, $46 \mathrm{ml}$ of distilled water and $1 \mathrm{ml}$ of Folin-Ciocalteu reagent and the content was mixed thoroughly. After $3 \mathrm{~min}, 3 \mathrm{ml}$ of $2 \% \mathrm{Na}_{2} \mathrm{CO}_{3}$ was added and then the mixture was allowed to stand in dark for $2 \mathrm{~h}$ with intermittent shaking. The absorbance was measured at $760 \mathrm{~nm}$. The index of TPC in the mixture was determined as $\mu \mathrm{gmg}^{-1}$ of gallic acid equivalent (GAE) using an equation obtained from the calibration curve of gallic acid graph ${ }^{35}$.

\section{Determination of Total Flavonoid Concentration (TFC)}

The total flavonoid content of the essential oil of L. crispata was determined by spectrophotometry, using aluminium chloride method and quercetin as standard. Briefly, $1.0 \mathrm{ml}$ of the essential oil, $0.10 \mathrm{ml}$ of $10 \%$ aluminium chloride $\left(\mathrm{AlCl}_{3} \cdot 6 \mathrm{H}_{2} \mathrm{O}\right), 0.10 \mathrm{ml}$ of sodium acetate $\left(\mathrm{NaC}_{2} \mathrm{H}_{3} \mathrm{O}_{2} .3 \mathrm{H}_{2} \mathrm{O}\right)(1 \mathrm{M})$ and $2.80 \mathrm{ml}$ of distilled water. After incubation for $40 \mathrm{~min}$, absorbance was measured at $415 \mathrm{~nm}$ using a UV-Visspectrophotometer. To calculate the concentration of flavonoids, a calibration curve was made using quercetin as standard. The index of TFC concentration is expressed as quercetin equivalents (QE) in $\mu \mathrm{g}$ per $\mathrm{mg}$ of juice. All assays were carried out in triplicate ${ }^{36}$.

\section{Determination of Total Ascorbic acid content (TAAC)}

A sample of $1.0 \mathrm{ml}$ was added to $1.0 \mathrm{ml}$ of 2,4-dinitrophenylhydrazine (2,4-DNPH). It was allowed to stand for $30 \mathrm{~min}$. and the absorbance was read in triplicate at $515 \mathrm{~nm}$, using distilled water as blank. Ascorbic acid was used as a reference and for the calibration curve. The result was expressed in milligram per gram of ascorbic acid equivalent ${ }^{37}$.

\section{Determination of Anti-radical Potential}

\section{(i) Phosphomolybdate Total Antioxidant Capacity (PTAC) Assay}

The PTAC of the essential oil of L crispata was determined with phosphomolybdenum using ascorbic acid as the standard. An aliquot of $1.0 \mathrm{ml}$ of the extract solution was combined with $1.0 \mathrm{ml}$ of reagent (0.6 M sulphuric acid, $28 \mu \mathrm{M}$ sodium phosphate and $4 \mu \mathrm{M}$ ammonium molybdate). The tubes were capped and incubated in a boiling water bath at $95{ }^{\circ} \mathrm{C}$ for $90 \mathrm{~min}$. after the sample had cooled to room temperature, the absorbance of the aqueous solution of each were measured at $695 \mathrm{~nm}$ in UV spectrophotometer. The blank solution contained $1.0 \mathrm{ml}$ of reagent solution and the appropriate volume of the same solvent used for the sample and it was incubated under same conditions as the rest of the sample. The total antioxidant capacity was expressed as equivalents of ascorbic acid ${ }^{39}$.

\section{(ii) 2,2'-Diphenyl-1-picrylhydrazil (DPPH) Antioxidant Assay}

The DPPH antioxidant and free radical scavenging of the essential oil was determined using DPPH method ${ }^{40}$. Briefly stock solution of the essential oil $\left(1.0 \mathrm{mgml}^{-1}\right)$ was diluted in methanol to different concentrations of 1000,100 and $10 \mathrm{\mu gml}^{-1}$. Methanolic DPPH $(0.1$ $\mathrm{mM}$ ) solution was prepared freshly and $1.0 \mathrm{ml}$ was added to varying concentrations of the extract. The mixture was allowed to stand for $30 \mathrm{mins}$ in the dark at room temperature for proper incubation with shaking at regular interval. The absorbance was measured at $517 \mathrm{~nm}$ using Uniscope SM 7504 UV Spectrophotometer against a blank containing all reagents except the test sample. Ascorbic acid was used as the positive control. Assays were carried out in triplicate. The percentage DPPH radical inhibition was calculated using the following equation:

$I \%_{\text {DPPH }}{ }^{*}=\frac{A_{\text {blank }}-A_{\text {ext }}}{A_{\text {blank }}} \times 100$

$\mathrm{A}_{\mathrm{o}}$ is the absorbance of the blank solution and $\mathrm{A}$ is the absorbance of the essential oil. The $\mathrm{IC}_{50}$, the concentration giving $50 \%$ inhibition of $\mathrm{DPPH}$, was read off a graph of I\% (percentage inhibition) versus extract concentration $^{40}$.

DPPH Antioxidant Activity Index (AAI): The AAI was calculated using the formula:

$A A I=\frac{D P P H^{*} \text { Initial Concentration }}{\mathrm{IC}_{50}}$

AAI value of $<0.5$ was rated as weak; $0.5-1.0$ was considered as moderate; 1.0-2.0 was classified as strong, and value $>2.0$ was considered as very strong $^{40}$.

\section{Analysis for bactericidal activity}

The antibacterial potential of the essential oil was determined using Agar-well diffusion method against thirteen bacteria isolates obtained 
from clinical samples. Six of the isolates were Gram positive namely Bacillus sp, Enterococcus faecalis, Micrococcus varians, Streptococcus agalactiae, Staphylococcus aureus and Staphylococcus asaprophyticus, while the remaining seven isolates were Gram negative bacteria namely Escherichia coli, Klebsiella pneumoniae, Proteus mirabilis, Pseudomonas aeruginosa, Salmonella typhimurium, Serratia marcescens and Shigella dysenteriae. The organisms were incubated and grown overnight at 37 ${ }^{\circ} \mathrm{C}$ in Nutrient broth. The cultured bacteria broth were adjusted to 0.5 McFarland standards, $20 \mathrm{ml}$ of sterilized Mueller Hinton agar medium was homogenized and aseptically poured into sterile Petri dishes and the plates were swabbed with inocula of the test organisms, and kept for $30 \mathrm{~min}$. for adsorption. A sterile cork borer of $6 \mathrm{~mm}$ diameter was used to make uniform wells into which were added different concentrations $\left(1000,500\right.$ and $\left.250 \mathrm{\mu gml}^{-1}\right)$ of the essential oil solution. The plates were allowed to stay in a refrigerator for 1 hour to allow proper diffusion of the extract solution into the medium. Synthetic antibiotic gentamicin $(30 \mu \mathrm{g} / \mathrm{disc})$ was used as positive control. The plates were then incubated at $37^{\circ} \mathrm{C}$ for $18-24 \mathrm{hrs}$ before visual assessment of the inhibition zones. The zone of inhibition was measured to the nearest size in millimetre $(\mathrm{mm})$ using standard rule. The assay was carried out under aseptic conditions in order to achieve consistency ${ }^{41}$.

\section{RESULTS AND DISCUSSION}

In this study, the essential oil of the aerial of L. crispata was investigated for its chemical constituents. The colour of the essential oil was whitish. The oil exuded a sweet aromatic odour. The GC-MS analysis of the essential oil of the aerial of $L$. crispata showed the presence of thirty-five (35) medicinally active compounds making up $89.83 \%$ of the oil (Table 1). The most abundant component was phenolic compound called 2-tert-butyl-1,4-dimethoxybenzene (28.3\%), . The other major terpenoids present in the oil were $\alpha$-humulene (6.9\%) and (+)-sabinene $(5.9 \%)$. The principal classes of organic compounds in the aerial essential oil were polar and non-polar organic compounds. The chemical composition of this aerial essential oil is different from those reported in other studies for some related species such as those reported for L. tomentos $a^{42}$, L. decurrens $^{43}$, L. aurita $^{44,45}$, L. alata $^{46}$ and L. pterodonta ${ }^{47,48}$.

\section{Total Phenolic, Flavonoid, Total Ascorbic Acid Contents}

The TPC, TFC and AAS analyses of the investigated aerial essential oil of $L$. crispata showed the presence of high amount of polyphenol, flavonoid and ascorbic acid (Figure 1). The total phenolic content (TPC) of the essential oil was $172.75 \pm 0.00 \mu \mathrm{gmg}^{-1} \mathrm{GAE}$ (Figure1). The quantitative amount of flavonoids in the essential oil of $L$. crispata evaluated in this study was $48.69 \pm 0.00 \mu \mathrm{gmg}^{-1} \mathrm{QE}$ (Figure 2). The essential oil of $L$. crispata had high amount $\left(61.85 \pm 0.00 \mu \mathrm{gmg}^{-1} \mathrm{AAE}\right)$ of vitamin $\mathrm{C}$ and its derivatives present in the aerial of the medicinal plant (Figure 3). Comparatively, extract and fractions from Laggera aurita grown in Burkina Faso has phenolic and flavonoid contents $62.12 \pm 0.68$ mgGAE and $10.56 \pm 0.29 \mathrm{mgQE}$, respectively ${ }^{49}$. Natural phenolic and flavonoid compounds play many significant roles in human health as evident from their therapeutic properties ${ }^{50}$. Plants consumed by humans may contain thousands of different phenolic and flavonoid components. The effect of dietary phenolics is currently of great interest due to their antioxidative and possible anticarcinogenic activities ${ }^{16}$. Phenolic and flavonoid compounds also function as reducing agents, free radical scavengers, and quenchers of singlet oxygen formation. In addition, phenolic and flavonoid components play important roles in the control of many human diseases ${ }^{51}$.

\section{Total Antioxidant Capacity (TAC)}

The total antioxidant of the essential oil of L. crispata was found to be moderately high $\left(726.92 \pm 0.00 \mu \mathrm{gmg}^{-1} \mathrm{AAE}\right)$ as shown in Figure 1. The phosphomolybdate method is a quantitative method for determining
Table 1: Chemical Composition of the Aerial Essential Oil of Laggera crispate.

\begin{tabular}{|c|c|}
\hline Compound & $\begin{array}{l}\text { Percentage } \\
\text { Composition }\end{array}$ \\
\hline 2-tert-butyl-1,4-dimethoxybenzene & 28.3 \\
\hline 2-methylene-4,8,8-trimethyl-2-vinyl-bicyclo[5.2.0]nonane & 3.0 \\
\hline 1,1,4,8-tetramethyl-cis,cis,4,7,10-cycloundecatriene & 3.0 \\
\hline$\beta$-gurjunene & 4.5 \\
\hline 1-(1,5-dimethyl-4-methylbenzene & 3.0 \\
\hline ar-curcumene & 2.0 \\
\hline$\beta$-dihydroagarofuran & 1.1 \\
\hline epi-globulol & 0.6 \\
\hline$\gamma$-eudesmol & 1.0 \\
\hline Guaiol & 0.6 \\
\hline 1-heptatriacotanol & 0.6 \\
\hline 1-pentyloctylbenzene & 2.3 \\
\hline hexahydrofarnesyl acetone & 2.0 \\
\hline 1,54-dibromotetrapentacontane & 1.0 \\
\hline 1-(+)-ascorbic acid 2,6-dihexadecanoate. & 2.5 \\
\hline 2-dodecen-1-y(-)succinic anhydride & 1.0 \\
\hline 5,9-dimethyl-4,8-decadienal & 1.0 \\
\hline Phytol & 1.0 \\
\hline Dihydrovallesiachotamine & 3.0 \\
\hline bis(dodecanamido)methane & 3.8 \\
\hline Erucylamide & 1.5 \\
\hline bis(tridecyl)phthalate & 1.0 \\
\hline (+)-sabinene & 5.9 \\
\hline$\alpha$-phellandrene & 1.0 \\
\hline 3-(4-methylbenzoyl)-2-thioxo-4-thiazolyl-4-methylbenzoate & 0.1 \\
\hline 2,2-dichloro-1-methylcyclohexanol & 0.2 \\
\hline 1,2-diisopropenylcyclobutane & 0.4 \\
\hline Caryophyllene & 4.3 \\
\hline$\alpha$-humulene & 6.9 \\
\hline$\beta$-copaene & 3.0 \\
\hline 2-(5-Isoxazolyl)phenol & 0.01 \\
\hline 1,2-benzenediol, o-(4-butylbenzoyl)-o'-(2-methylbenzoyl) & 0.1 \\
\hline 7-epi- $\alpha$-eudesmol & 0.1 \\
\hline 2,4-pentadienoic acid, 1-cyclopenten-3-on-1-yl ester & 0.01 \\
\hline 2-amino- $4 \mathrm{H}$-chromen-4-one & 0.01 \\
\hline Percentage total & 89.83 \\
\hline
\end{tabular}

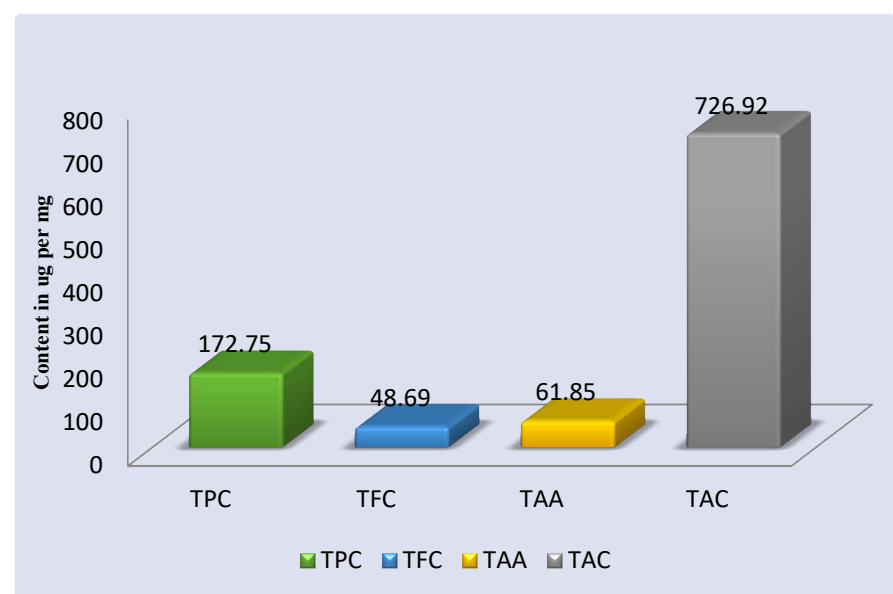

Figure 1: Polyphenol and Ascorbic Acid and Total Antioxidant Capacity. 
the total antioxidant capacity (TAC), which is expressed as ascorbic acid equivalents. This method gives a combined measure of the antioxidant activity of the range of chemically diverse phytochemicals present in the aerial essential oil of L. crispata as determined by the formation of the reduced phosphomolybdate complex ${ }^{52,53}$.

\section{In vitro DPPH Free Radical Scavenging Assay}

The DPPH percentage scavenging by the essential oil of $L$. crispata at different concentrations $\left(1000,100\right.$ and $10 \mu \mathrm{gml}^{-1}$ ) were $81.82,69.62$

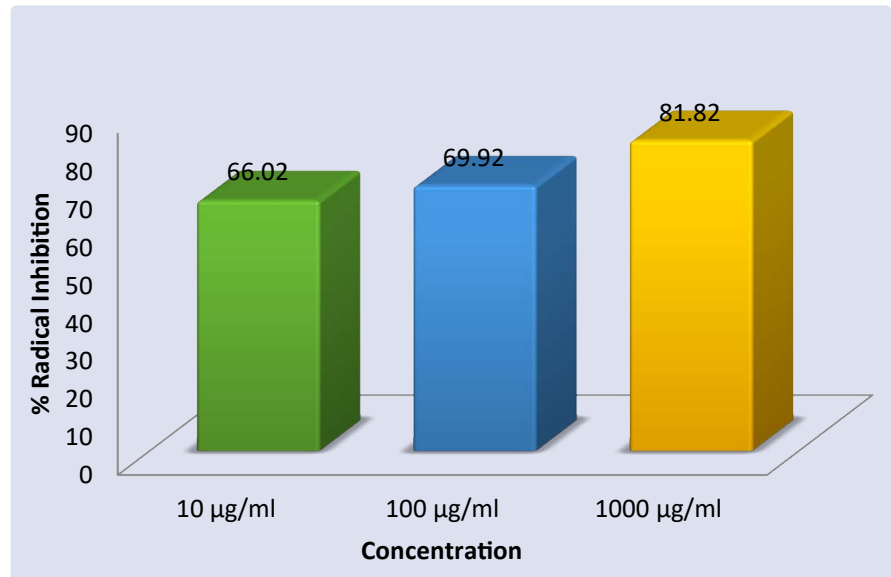

Figure 2: DPPH Antioxidant of the Aerial Essential oil.

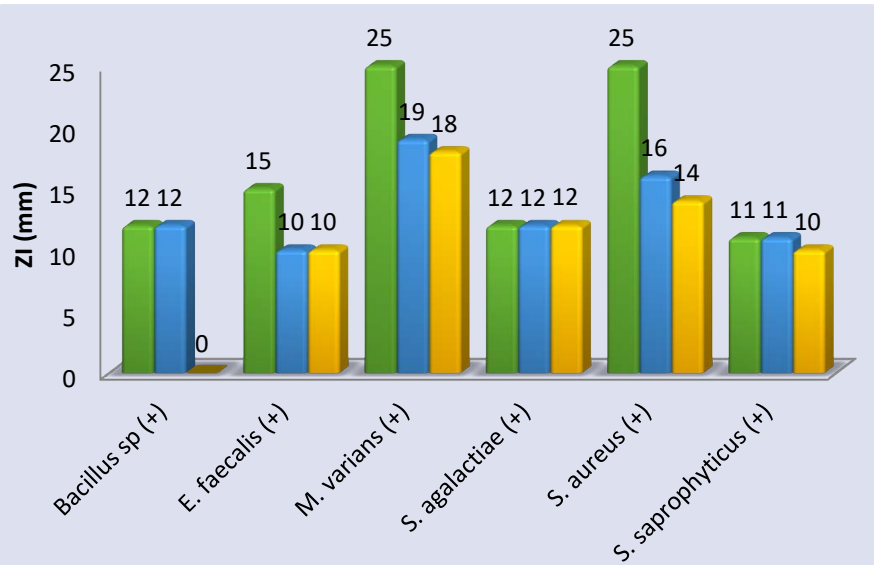

Figure 3: Zones of Inhibition $(\mathrm{mm})$ showing the Antimicrobial Potential of Aerial Essential Oil of L. crispata against Gram-positive bacteria.

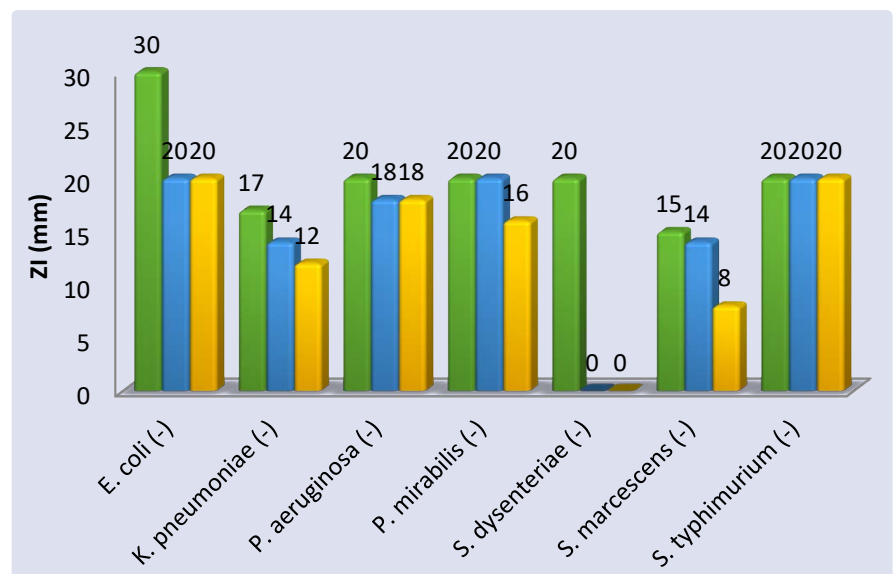

Figure 4: Zones of Inhibition $(\mathrm{mm})$ showing the Antimicrobial Potential of Aerial Essential Oil of L. crispata against Gram-negative bacteria.

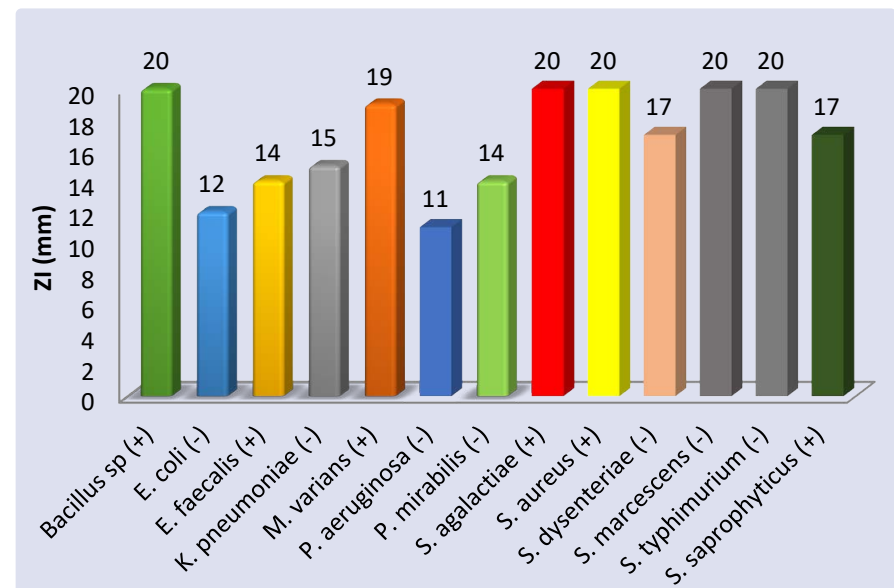

Figure 5: ZI $(\mathrm{mm})$ Showing the Gentamicin Susceptibility on the tested Gram Positive and Gram Negative.

and $62.02 \%$, respectively. The essential oil of $L$. crispata gave an $\mathrm{IC}_{50}$ value of $1.0 \mathrm{\mu gml}^{-1}$ and the AAI of the essential oil was 39.0 while the ascorbic acid (reference compound) had an $\mathrm{IC}_{50}$ value of $9.0 \mu \mathrm{gml}^{-1}$. With these very high percentage free radical scavenging, very low $\mathrm{IC}_{50}$ and very high AAI values, the essential oil was classified as a very strong natural antioxidant agent. The in vitro antioxidant potential of the aerial of the plant used in this study is greater than those of the related species such as the essential oil of other members of Laggera family such as Laggera tomentosa with $\mathrm{IC}_{50}$ of 0.33-0.39 $\mathrm{mgml}^{-154}$.

An antioxidant is a molecule capable of slowing or preventing the oxidation of other molecules, or as any substance that when present at low concentrations compared to those of an oxidizable substrate significantly delays or prevents oxidation of that substrate ${ }^{55,56}$. A free radical is a highly reactive molecule or chemical species that contains one or more unpaired electron. These unpaired electrons make the radical very reactive and cause oxidative stress, defined as an imbalance between oxidants and antioxidants in favour of the oxidants, potentially leading to damage ${ }^{57,58}$. Free radical is constantly generated in all living cells and is a part of normal cellular function. However, excess free radical originating from endogenous or exogenous sources are responsible for aging and causing various human diseases. Free radicals cause oxidative damage to different molecules, such as lipids, proteins and nucleic acids and thus are involved in the initiation phase of some degenerative diseases ${ }^{59-81}$. Research has shown that free radical mediated oxidative stress is among the major causative factors in induction of many chronic and degenerative diseases including atherosclerosis, ischemic heart disease, ageing, diabetes mellitus, cancer, immunosuppression, neurodegenerative diseases and others ${ }^{60,61}$.

\section{Antimicrobial Activities}

The antimicrobial activities of the aerial of L. crispata against Grampositive bacteria and Gram-negative bacteria are shown in figure 4-5. The essential oil showed variable activities against tested bacteria. The essential oil showed varying levels of effectiveness on all bacteria tested. The activities ranged as follows: Resistant $(-)$, not sensitive $(<8 \mathrm{~mm})$, sensitive $(9-14 \mathrm{~mm})$, very sensitive, $(15-19 \mathrm{~mm})$ and ultrasensitive (>20 mm). The highest inhibitory effect of the essential oil was observed against $E$. coli as depicted in figure 4. Other highly susceptible bacterium at $1000 \mathrm{ggml}^{-1}$ were $M$. varians ( $25 \mathrm{~mm}$ ), S. aureus (25), $P$. aeruginosa $(20 \mathrm{~mm})$, P. mirabilis $(20 \mathrm{~mm})$, S. typhimurium $(20 \mathrm{~mm})$ and $S$. dysenteriae $(20 \mathrm{~mm})$, K. Pneumonia $(17 \mathrm{~mm})$, S. marcescens $(15 \mathrm{~mm})$, E. faecalis $(15 \mathrm{~mm})$, S. agalactiae $(12 \mathrm{~mm})$, Bacillus sp $(12$ $\mathrm{mm})$ and $S$. saprophyticus $(11 \mathrm{~mm})$. This indicated that E. coli was highly susceptible compared to the other tested bacteria within the 
concentration of $1000 \mu \mathrm{gml}^{-1}$ of aerial essential oil of L. crispata in this study. At the concentration of $500 \mathrm{\mu gml}^{-1}$ of the essential oil, the bacteria inhibition activities was highest in E. coli $(20 \mathrm{~mm})$, P. mirabilis $(20$ $\mathrm{mm})$ and S. typhimurium $(20 \mathrm{~mm})$. These were followed by M. varians $(19 \mathrm{~mm})$, P. aeruginosa $(18 \mathrm{~mm})$, S. aureus $(16 \mathrm{~mm})$, K. pneumoniae (14 mm), S. marcescens (14 mm), S. agalactiae (12 mm), Bacillus $s p(12$ $\mathrm{mm})$ and S. saprophyticus $(11 \mathrm{~mm}) . S$. dysenteriae is resistance to the activity of the extract at $500 \mu \mathrm{gml}^{-1}$. The zones of inhibition observed when a concentration of $250 \mathrm{\mu gml}^{-1}$ of the essential oil was used against the bacterial isolates was significantly different compared to 1000 and $500 \mathrm{\mu gml}^{-1}$ concentration of the essential oil. At a lower concentration of $250 \mathrm{\mu gml}^{-1}$ of the essential oil, E. coli $(20 \mathrm{~mm})$ and S. typhimurium $(20 \mathrm{~mm})$ were more susceptible to the activity of the extract and gave high zones of inhibition. M. varians $(18 \mathrm{~mm})$, P. aeruginosa $(18 \mathrm{~mm})$, P. mirabilis (16 mm), S. aureus (14 mm), K. pneumoniae (12 mm), S. agalactiae $(12 \mathrm{~mm})$, E. faecalis $(10 \mathrm{~mm})$, and S. saprophyticus $(10 \mathrm{~mm})$ were also susceptible to the activities of the synergic activities of the secondary metabolites in the essential oil. Meanwhile, Bacillus sp and S. dysenteriae were resistance at this concentration of the essential oil. Comparatively, the essential oil investigated in this study showed a promising antibacterial potential than the previously studied species such as Laggera tomentosa where S. aureus and B. cereus showed very low zone of inhibition and E. coli and K. pneumonia showed resistance to the essential oil ${ }^{54}$. The tested bacteria were found to be sensitive to gentamicin (GEN) synthetic antibiotics. The observed antibacterial effects collaborate its traditional uses. In this work the essential oil of the plant inhibited the growth of Gram positive and Gram negative bacteria to a high degree. These thirteen bacteria used in this research are responsible for some of the various health related illnesses. Bactericidal activity may be due to presence of polyphenol, terpenoids and numerous free hydroxyls that have synergic capability to combine with the carbohydrates and proteins in the bacterial and destroy the cell wall ${ }^{63}$. It is confirmed that the aerial essential oil of L. crispata have greater potential as antibacterial compounds against micro flora and that they can be used in the treatment of infectious diseases caused by resistant pathogenic microorganisms in animals and human beings. The essential oil of higher plants can be a very good source of antibiotics against various bacteria pathogens. Plants which have antimicrobial compounds have enormous therapeutic potentials as they can act without any side effect as often observed with synthetic antimicrobial products ${ }^{64,65}$.

\section{CONCLUSION}

The aerial essential oil of L. crispata has abundant pharmacologically active compounds, such as terpenoids, polyphenols, fatty acids, which can be used as sources of new and useful antioxidant and antimicrobial chemical entities. The medicinal activities of the oil might be due to the synergistic actions of these constituent phytocompounds. Therefore, the plants have promising compounds to be tested as potential drugs for treatment of diseases resulting from reactive oxygen species and bacteria organisms. The results indicated that essential oil may be considered as potential drugs for treatments of ROS and RNS related diseases and reduced their systemic adverse effects. However, these findings warrant extensive further studies on chemical profiles such as isolation and structure clarification of pure compounds, and mechanistic action of antioxidant and antimicrobial activities.

\section{REFERENCE}

1. Tungmunnithum D, Thongboonyou A, Pholboon, A, Yangsabai A Flavonoids and Other Phenolic Compounds from Medicinal Plants for Pharmaceutical and Medical Aspects: An Overview. Medicines (Basel, Switzerland). 2018; 5(3): 93.
2. Anand $U$, Jacobo-Herrera N, Altemimi A, Lakhssassi N. A Comprehensive Review on Medicinal Plants as Antimicrobial Therapeutics: Potential Avenues of Biocompatible Drug Discovery. Metabolites. 2019; 9(11): 258. https://doi.org/10.3390/ metabo9110258

3. Gorlenko CL, Kiselev HY, Budanova EV, Zamyatnin AA, Ikryannikova LN. Plant Secondary Metabolites in the Battle of Drugs and Drug-Resistant Bacteria: New Heroes or Worse Clones of Antibiotics? Antibiotics (Basel, Switzerland). 2020; 9(4): 170. https://doi.org/10.3390/antibiotics9040170

4. Mickymaray S. Efficacy and Mechanism of Traditional Medicinal Plants and Bioactive Compounds against Clinically Important Pathogens. Antibiotics (Basel, Switzerland). 2019; 8(4): 257. https:// doi.org/10.3390/antibiotics8040257.

5. Seca A, Pinto D. Biological Potential and Medical Use of Secondary Metabolites. Medicines (Basel, Switzerland). 2019; 6(2): 66. https:// doi.org/10.3390/medicines6020066

6. Sofowora A, Ogunbodede E, Onayade A. The role and place of medicinal plants in the strategies for disease prevention. African journal of traditional, complementary, and alternative medicines: AJTCAM. 2013; 10(5): 210-229. https://doi.org/10.4314/ajtcam. v10i5.2

7. Benarba B. Pandiella A. Medicinal Plants as Sources of Active Molecules Against COVID-19. Front. Pharmacol. 2020; 11: 1-15.

8. Ololade ZS, Abam EO, Anuoluwa IA, Abiona OO. Secondary Metabolites, Pharmacognostic and Therapeutic Activities of the Rhizome Extract of Curcuma longa Grown in South-West, Nigeria, The Journal of Phytopharmacology. 2020; 9(1): 30-37.

9. Dolan LC, Matulka RA, Burdock GA. (2010). Naturally occurring food toxins. Toxins. 2010; 2(9): 2289-2332. https://doi.org/10.3390/ toxins 2092289

10. Yahyapour R, Shabeeb D, Cheki M, Musa AE, Farhood B, Rezaeyan A, Amini P, Fallah H, Najafi M. Radiation Protection and Mitigation by Natural Antioxidants and Flavonoids: Implications to Radiotherapy and Radiation Disasters. Current Molecular Pharmacology. 2018; $11(4), 285-304$

11. Onifade OF, Ayodele PF, Ololade ZS, Balogun DO. Mitigative Effects of Coconut Oil and Its Water on the Lungs of Male Albino Rats Exposed to Petrol Vapour, Biomedical Journal of Scientific and Technical Research. 2020; 25(1): 18865-18873.

12. Dar RA, Shahnawaz M, Rasool S, Qazi PH. Natural product medicines: A literature update. Journal of Phytopharmacology. 2017; 6(6): 340-342.

13. Cox-Georgian D, Ramadoss N, Dona C, Basu C. Therapeutic and Medicinal Uses of Terpenes. Medicinal Plants: From Farm to Pharmacy. 2019; 333-359.

14. Dhifi W, Bellili S, Jazi S, Bahloul N, Mnif W. Essential Oils' Chemical Characterization and Investigation of Some Biological Activities: A Critical Review. Medicines (Basel, Switzerland). 2016; 3(4): 25. https://doi.org/10.3390/medicines3040025

15. Taghvaei M, Jafari SM. Application and stability of natural antioxidants in edible oils in order to substitute synthetic additives. Journal of food science and technology. 2015; 52(3): 1272-1282.

16. Ololade ZS, Ogunmola OO, Kuyooro SE, Abiona OO. Stachytarpheta jamaicensis Leaf Extract: Chemical Composition, Antioxidant, AntiArthritic, Anti-Inflammatory and Bactericidal Potentials, Journal of Scientific and Innovative Research. 2017; 6(4): 119-125.

17. Sharifi-Rad J, Sureda A, Tenore GC, Daglia M, Sharifi-Rad M, Valussi M, Tundis R, Sharifi-Rad M, Loizzo MR, Ademiluyi AO, Sharifi-Rad R, Ayatollahi SA, Iriti M. Biological Activities of Essential Oils: From Plant Chemoecology to Traditional Healing Systems. Molecules (Basel, Switzerland). 2017; 22(1), 70. https://doi.org/10.3390/ molecules22010070 
18. Sarkic A, Stappen I. Essential Oils and Their Single Compounds in Cosmetics-A Critical Review. Cosmetics. 2018; 5(1):11. https://doi. org/10.3390/cosmetics5010011

19. Ololade ZS, Olawore NO, Olasoji SO, Anosike SO. Chemical Composition and Bactericidal Activities of the Leaf Essential Oil of Eucalyptus maculata Hook, Natural Product Chemistry and Research. 2017; 5(2): 1-4.

20. Raveau R, Fontaine J, Lounes-Hadj Sahraoui A. Essential Oils as Potential Alternative Biocontrol Products against Plant Pathogens and Weeds: A Review. Foods (Basel, Switzerland). 2020; 9(3): 365. https://doi.org/10.3390/foods9030365.

21. Pandey AK, Kumar P, Singh P, Tripathi NN, Bajpai VK. Essential Oils: Sources of Antimicrobials and Food Preservatives. Frontiers in microbiology. 2017; 7: 1-14. https://doi.org/10.3389/ fmicb.2016.02161

22. Elshafie HS, Camele I. An Overview of the Biological Effects of Some Mediterranean Essential Oils on Human Health. BioMed research international. 2017; 9268468. https://doi.org/10.1155/2017/9268468

23. Astani A, Reichling J, Schnitzler P. Screening for antiviral activities of isolated compounds from essential oils. Evidence-based complementary and alternative medicine: eCAM. 2011, 253643. https://doi.org/10.1093/ecam/nep187

24. Tariq S, Wani S, Rasool W, Shafi K, Bhat MA, Prabhakar A, Shalla $\mathrm{AH}$, Rather MA. A comprehensive review of the antibacterial, antifungal and antiviral potential of essential oils and their chemical constituents against drug-resistant microbial pathogens. Microb Pathog. 2019;134:103580. doi: 10.1016/j.micpath.2019.103580.

25. Silva JKRD, Figueiredo PLB, Byler KG, Setzer WN. 2020. Essential Oils as Antiviral Agents. Potential of Essential Oils to Treat SARSCoV-2 Infection: An In-Silico Investigation. International Journal of Molecular Science. 2020; 12: 21(10), 3426. doi: 10.3390/ ijms21103426. PMID: 32408699; PMCID: PMC7279430.

26. Tshibangu DST, Matondo A, Lengbiye EM, Inkoto CL, Ngoyi EM et al. (2020). Possible Effect of Aromatic Plants and Essential Oils against COVID-19: Review of Their Antiviral Activity, Journal of Complementary and Alternative Medical Research. 2020; 11(1): 10-22.

27. Swamy MK, Akhtar MS, Sinniah UR. Antimicrobial Properties of Plant Essential Oils against Human Pathogens and Their Mode of Action: An Updated Review. Evidence-based complementary and alternative medicine: eCAM, 2016; 3012462. https://doi. org/10.1155/2016/3012462

28. Romeo I, Mesiti F, Lupia A, Alcaro S. Current Updates on Naturally Occurring Compounds Recognizing SARS-CoV-2 Druggable Targets. Molecules. 2021; 26(3): 632. https://doi.org/10.3390/ molecules 26030632

29. Asif M, Saleem M, Saadullah M, Yaseen HS, Al Zarzour R. COVID-19 and therapy with essential oils having antiviral, anti-inflammatory, and immunomodulatory properties. Inflammopharmacology. 2020; 28(5): 1153-1161.

30. Ololade ZS, Fakankun OA, Alao FO, Udi OU. Ocimum basilicum var. purpureum Floral Essential Oil: Phytochemicals, Phenolic Content, Antioxidant, Free Radical Scavenging, Antimicrobial Potentials. Global Journal of Science Frontier Research. 2014; 14(7): 31-38.

31. Ram SV, Rajendra CP, Sajendra KV, Amit C. Mahendra PD. Chemical Composition and Antibacterial Activity of the Essential Oils of Laggera crispata (Vahl) Hepper and Wood, Cyclospermum leptophyllum (Pers.) Eichler and Perilla frutescens (L.) Britton, Analytical Chemistry Letters, 2015; 5(3): 162-171.

32. Verma RS, Padalia RC, Chauhan A. Compositional Variation in the Essential Oils of Vegetative and Reproductive Parts of Laggera crispata (Vahl) Hepper and Wood. National Academic of Science Letter. 2013; 36: 447-451

33. Qiu YH, Yang YF, Tan JM, Tan CH, Chang J. Laggeric acid, a novel seco-eudesmane sesquiterpenoid from Laggera crispate. Journal of Asian Natural Product Research. 2014; 16(3): 318-22.
34. Ololade ZS, Olawore NO. 2017. Characterization of Essential Oil from the Seed of Eucalyptus cloeziana and Evaluation of its Modes of Medicinal Potentials. Edorium Journal of Infectious Diseases. 2017; 3: 1-8.

35. Alvarez R, Araya H, Navarro-Lisboa R, Lopez de Dicastillo C. Evaluation of Polyphenol Content and Antioxidant Capacity of Fruits and Vegetables Using a Modified Enzymatic Extraction. Food technology and biotechnology. 2016; 54(4), 462-467.

36. Nicu Al, Pirvu L, Vamanu AV, Stoian G. The European beech leaves extract has an antibacterial effect by inducing oxidative stress. Romanian Biotechnological Letters. 2016; 22(6):12071- 12080.

37. Benites RSR, Formagio ASN, Argandona EJS, Volobuff CRF, Trevizan LNF, Vieira, MC, Silva MS.Contents of constituents and antioxidant activity of seed and pulp extracts of Annona coriacea and Annona sylvatica, Brazilian Journal of Biology. 2015; 75(3),685-691.

38. Ololade ZS, Abiose MM. Analyses of the Secondary Metabolites, Radical Scavenging, Protein Denaturation and Antibacterial Activities of the Stem Extract of Annona squamosa. Nigerian Journal of Science. 2019; 53(1): 39-54.

39. Akar Z, Kucuk M. Dogan H. A new colorimetric DPPH• scavenging activity method with no need for a spectrophotometer applied on synthetic and natural antioxidants and medicinal herbs. Journal of enzyme inhibition and medicinal chemistry. 2017; 32(1), 640-647. https://doi.org/10.1080/14756366.2017.1284068

40. Hartati R, Nadifan HI, Fidrianny I. Crystal Guava (Psidium guajava L. "Crystal"): Evaluation of In Vitro Antioxidant Capacities and Phytochemical Content. Scientific World Journal. 2020; doi: 10.1155/2020/9413727. PMID: 32952456; PMCID: PMC7481951.

41. Alao FO, Ololade ZS, Nkeonye CV. Phytochemicals and Antibacterial Potentialsof Senna tora Leaf and Seed Extracts on Some Clinically Isolated Bacteria, Journal of Bacteriology and Parasitology. 2018; 9(3): 1-4.

42. Getahun T, Sharma V, Gupta N. The genus Laggera (Asteraceae)Ethnobotanical and Ethnopharmacological Information, Chemical Composition as well as Biological Activities of Its Essential Oils and Extracts: A Review, Chemistry and Biodiversity. 2019; 16: 1-23.

43. Mothana RA, Alsaid MS, Al-Musayeib NM. Phytochemical analysis and In Vitro antimicrobial and freeradical-scavenging activities of the essential oils from Euryops arabicus and Laggera decurrens. Molecules. 2011; 16: 5149-5158.

44. Shahwar D, Ahmad N, Khan MA, Ullah S, Ahmad N. Chemical composition and biological activities of the essential oil of Laggera aurita Linn (DC.) grown in Pakistan, Turkish Journal of Biochemistry. 2012; 37(3): 329-335.

45. Getahun T, Sharma V, Kumar D, Gupta N. Chemical composition, and antibacterial and antioxidant activities of essential oils from Laggera tomentosa Sch. Bip. ex Oliv. et Hiern (Asteraceae). Turkish journal of chemistry. 2020; 44(6): 1539-1548.

46. Ollengo MA, Vulule JM, Matasyoh JC. Isolation, Structure Elucidation and Larvicidal Activity of Laggera alata Extracts. Res. J. Pharmacogn Phytochem. 2016; 8, 153.

47. Gu JL, Njateng GSS, Li ZJ, Zhang HX, Dai Q, Du ZZ. Chemical Composition and Antimicrobial Activities of Essential Oils of Laggera pterodonta Collected in Four Different Locations in Yunnan, China', Plant Dis. 2014; 36, 116-122.

48. Guo SS, Zhang WJ, You CX, Liang JY, Yang K, Geng ZF, Du SS, Wang CF. Chemical composition of essential oil extracted from Laggera pterodonta and its bioactivities against two stored product insects. Journal Food Processing and Preservation. 2017; 41, e12941

49. Dibala $\mathrm{Cl}$, Konate $\mathrm{K}$, Diao $\mathrm{M}$, Ouedraogo $\mathrm{M}$, Dicko $\mathrm{MH}$. Phytoconstituents Analysis, Antioxidant Capacity And Antimicrobial Properties Of Extracts From Laggera aurita L. (Asteraceae). International Journal of Pharmacy and Pharmaceutical Sciences, 2014; 6(7): 172-8. 
50. Ansari MA, Anurag A, Fatima Z, Hameed S. Natural Phenolic Compounds: A Potential Antifungal Agent. Formatex. 2013; 1189-1195.

51. Ololade ZS, Olawore NO. Chemistry and Medicinal Potentials of the Seed Essential Oil of Eucalyptus toreliana F. Muell Grown in Nigeria. Global Journal of Science Frontier Research. 2013; 13(3): 1-10.

52. Hanafey FM. Assessment of Total Antioxidant Capacity and Antiradical Scavenging Activity of Three Egyptian Wild Plants. Journal of Medical Sciences. 2013; 13: 546-554.

53. Torres-Martinez R, Garcia-Rodriguez YM, Rios-Chavez P, SaavedraMolina A, Lopez-Meza JE, Ochoa-Zarzosa A, Garciglia RS. Antioxidant Activity of the Essential Oil and its Major Terpenes of Satureja macrostema (Moc. and Sesse ex Benth.) Briq. Pharmacognosy magazine. 2018; 13(4), S875-S880.

54. Getahun, T., Sharma, V., Kumar, D. And Gupta, N. 2020. Chemical composition, and antibacterial and antioxidant activities of essential oils from Laggera tomentosa Sch. Bip. ex Oliv. et Hiern (Asteraceae). Turkish Journal of Chemistry. 44: 1539-1548.

55. Kurutas E. B. (2016). The importance of antioxidants which play the role in cellular response against oxidative/nitrosative stress: current state. Nutrition Journal. 15(1), 71. https://doi.org/10.1186/s12937016-0186-5.

56. Tan BL, Norhaizan ME, Liew WP, Sulaiman RH. Antioxidant and Oxidative Stress: A Mutual Interplay in Age-Related Diseases. Frontiers in pharmacology. 2018; 9, 1162. https://doi. org/10.3389/fphar.2018.01162

57. Phaniendra A, Jestadi DB, Periyasamy L. Free radicals: properties, sources, targets, and their implication in various diseases. Indian journal of clinical biochemistry: IJCB. 2015; 30(1): 11-26. https:// doi.org/10.1007/s12291-014-0446-0
58. Sharifi-Rad M, Kumar NVA, Zucca P, Varoni EM, Dini L, Panzarini E, Rajkovic J, Fokou PVT, Azzini E, Peluso I, Mishra, AP, Nigam M, El Rayess Y, Beyrouthy ME, Polito L, Iriti M, Martins N, Martorell M, Docea AO, Setzer WN, Sharifi-Rad J. Lifestyle, Oxidative Stress, and Antioxidants: Back and Forth in the Pathophysiology of Chronic Diseases. Frontiers in physiology. 2020; 11: 694. https://doi. org/10.3389/fphys.2020.00694

59. Lobo V, Patil A, Phatak A, Chandra N. Free radicals, antioxidants and functional foods: Impact on human health. Pharmacognosy reviews. 2010; 4(8): 118-126. https://doi.org/10.4103/0973-7847.70902

60. Pizzino G, Irrera N, Cucinotta M, Pallio G, Mannino F, Arcorac V, Squadrito F, Altavilla D, Bitto A. Oxidative Stress: Harms and Benefits for Human Health, Oxidative Medicine and Cellular Longevity. 2017; 17: 1-13.

61. Sawant PD. Potential Use of Spin Traps to Control ROS in Antipollution Cosmetics-A Review. Cosmetics. 2018; 5(1): 8. https://doi.org/10.3390/cosmetics5010008

62. Khatoon M, Islam E, Islam R, Rahman AA, Alam AK, Khondkar P, Rashid M, Parvin S. Estimation of total phenol and in vitro antioxidant activity of Albizia procera leaves. BMC Res Notes. 2013; 6: 121 https://doi.org/10.1186/1756-0500-6-121.

63. Nazzaro F, Fratianni F, Martino LD, Coppola R, Feo V. Effect of Essential Oils on Pathogenic Bacteria. Pharmaceuticals. 2013; 6: 1451-1474.

64. Aleksic $V$, Knezevic P. Antimicrobial and antioxidative activity of extracts and essential oils of Myrtus communis L. Microbiological Research. 2014; 169: 240-254.

65. Ugboko HU, Nwinyi OC, Oranusi SU, Fatoki TH, Omonhinmin CA. Antimicrobial Importance of Medicinal Plants in Nigeria. The Scientific World Journal. 2020, 7059323. https://doi. org/10.1155/2020/7059323

\section{GRAPHICAL ABSTRACT}

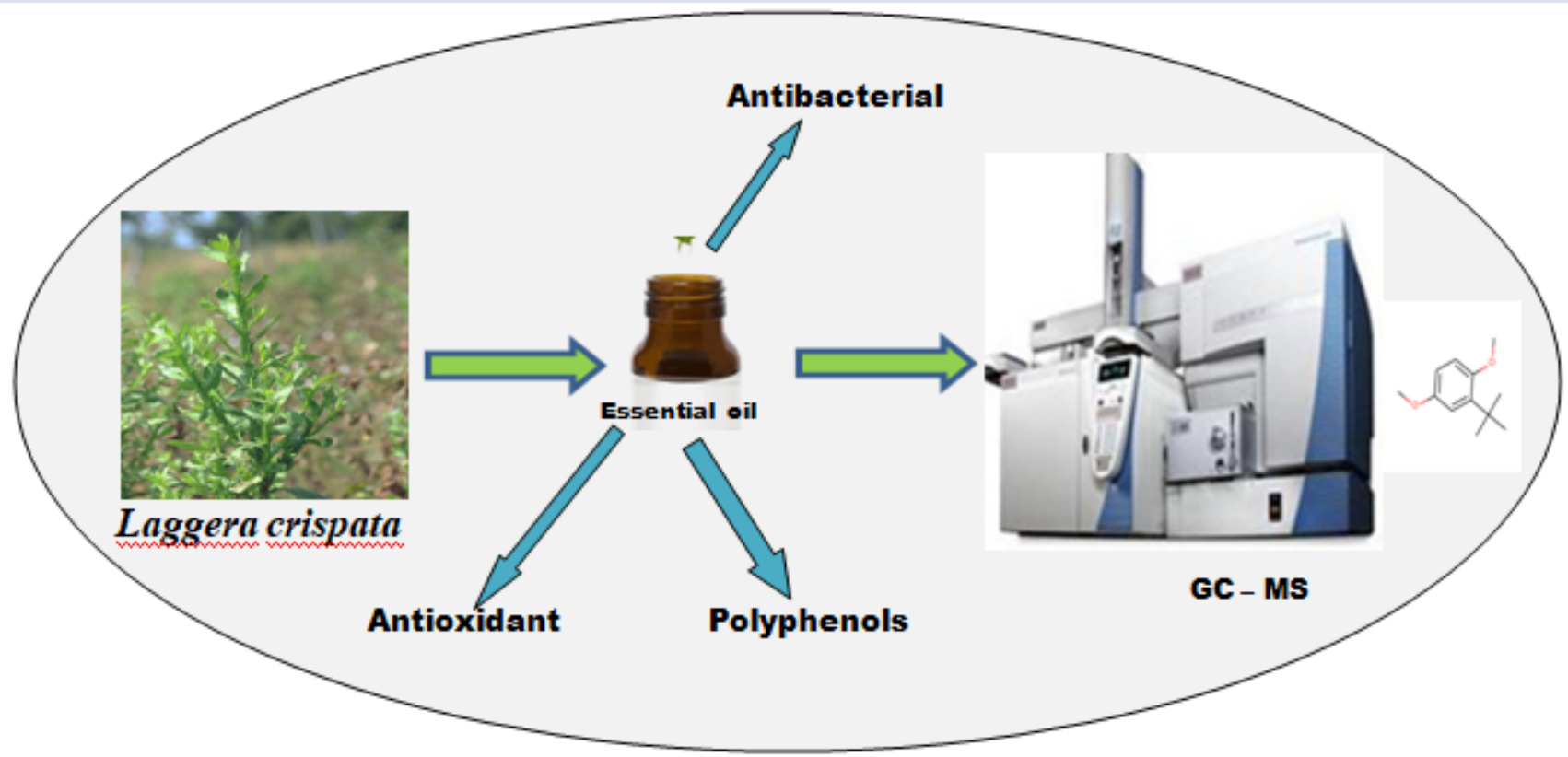




\section{ABOUT AUTHORS}

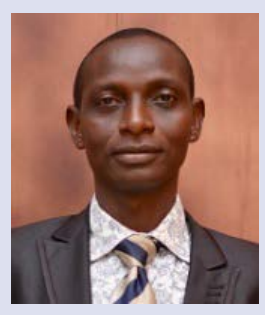

Doctor Zacchaeus S. Ololade is a Senior Lecturer in the Department of Chemistry, University of Medical Sciences, Ondo, Nigeria. His area of specialization is Organic Medicinal Chemistry and Pharmacognosy. He obtained his B.Tech, M.Tech and Ph.D Degrees from Ladoke Akintola University of Technology, Ogbomoso, Nigeria. Dr. Ololade has had the privilege of cognate teaching, research and administrative experiences in Universities and other tertiary institutions in Nigeria. He has many scientific journal publications. Records of his research publications have been read, cited and requested by many scientists globally. He has supervised and co-supervised many undergraduate and post-graduate students.

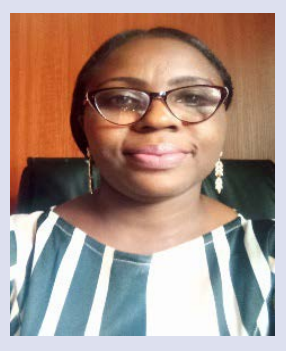

Dr. Iyadunni A. ANUOLUWA is a Senior Lecturer at the Department of Biological Sciences, University of Medical Sciences, Ondo, Nigeria. She holds a first degree in Microbiology from the University of Ado Ekiti now Ekiti State University. She had her master's and doctoral degree in Environmental Microbiology from the University of Ibadan. As an Environmental and Public Health Microbiologist, she is interested in the bioremediation of polluted/contaminated environment and the use of various medicinal plants and antibiotics to combat the incidence of antibiotic resistance as a means of ultimately improving the overall health of the environment and its inhabitant.

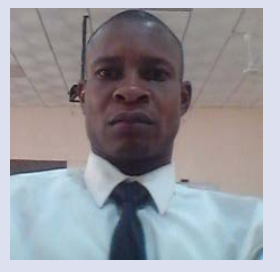

Dr. Adewale F. Adeyemi is a Lecturer I in the Department of Chemistry, University of Medical Sciences, Ondo, Nigeria. He is a holder of a holder of B.Sc. (Chemistry), M.Sc. (Chemistry) and Ph.D (Applied Chemistry) from Obafemi Awolowo University, Ile-lfe, Nigeria. His major areas of specialization span Physical and Organic Chemistry and their applications with special interest in waste management, fuel and natural products chemistry and conversions. He has co-authored a number of articles in international refereed journal.

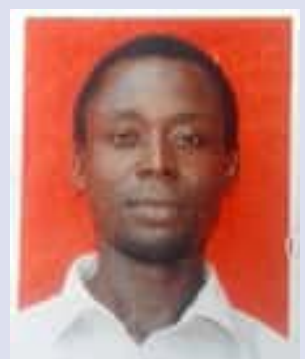

Mr. Uyaboerigha Daubotei Iba is a Postgraduate Student in the Department of Plant Biology and Biotechnology, University of Benin, Benin City, Edo State, Nigeria. His area of specialization is Ecology and and Biotechnology. He obtained his B.Sc and M.Sc Degrees from Obafemi Awolowo University, Ile-Ife, Nigeria and University of Benin, Benin City, Nigeria, respectively.

Cite this article: Ololade Z.S., Anuoluwa I.A., Adeyemi A.F. Uyaboerigha D.I. Synergistic Efficacy of Phytochemical, Antioxidant and Bactericidal Properties of the Aerial Essential Oil of Laggera crispate. Pharmacogn J. 2021;13(5): 1304-1311. 